\title{
Excretion of Glycolate by Thiobacillus neapolitanus Grown in Continuous Culture
}

\author{
Y. Cohen*, I. de Jonge, and J. G. Kuenen \\ Department of Microbiology, Biological Centre, Kerklaan 30, 9751 NN Haren, The Netherlands
}

\begin{abstract}
Thiobacillus neapolitanus grown in minerals medium in a thiosulfate-limited chemostat excreted $15 \%$ of all the carbon dioxide fixed as ${ }^{14} \mathrm{C}$-organic compounds at a dilution rate $(D)$ of $0.03 \mathrm{~h}^{-1}$. At $D$ $=0.36 \mathrm{~h}^{-1}$ this excretion was $8.5 \%$. Up to a $D$ of $0.2 \mathrm{~h}^{-1}$ glycolate was the major excretion product. Glycolate excretion was maximal at a $\mathrm{O}_{2}$ of $100 \%$ air saturation (a.s.) and not detectable at a $\mathrm{pO}_{2}$ of $5 \%$ (a.s.). Increasing the $p \mathrm{CO}_{2}$ of the gassing mixture to $5 \%$ $(\mathrm{v} / \mathrm{v})$, at a $\mathrm{pO}_{2}$ of $50 \%$ a.s. resulted in a lowering of the glycolate excretion from $3.5 \%$ of the total $\mathrm{CO}_{2}$ fixed to $1.8 \%$. These results indicate that glycolate excretion in $T$. neapolitanus is due to oxygenase activity of $D$-ribulose-1,5-bisphosphate carboxylase. HPMS (2-pyridylhydroxymethanesulfonate), an inhibitor of glycolate metabolism, did not stimulate the glycolate production in $T$. neapolitanus. Glycolate excretion was not observed in thiosulfate-limited chemostat cultures of the obligately chemolithotrophic Thiomicrospira pelophila or in thiosulfate- or formate-grown cultures of the facultatively chemolithotrophic Thiobacillus A2.
\end{abstract}

Key words: Thiobacillus neapolitanus, $\mathrm{CO}_{2}$ fixation, excretion products - Glycolate - Ribulose bisphosphate carboxylase/oxygenase - Chemolithotrophs Continuous culture.

It has been known for many years that obligately chemolithotrophic bacteria like Thiobacillus and Nitrobacter excrete organic compounds into their growth medium. This may at least in part explain why

\footnotetext{
* Present address: Marine Biology Laboratory, P.O.B. 469, Elat, Israel

Abbreviation: 2-pyridylhydroxymethanesulfonate $=$ HPMS
}

such cultures grown in purely inorganic medium are notorious for getting contaminated by heterotrophic bacteria. Several investigations by Umbreit and his coworkers (Borichewski and Umbreit, 1966; Borichewski, 1967; Pan and Umbreit, 1972a) and by Schnaitman and Lundgren (1965) have shown that one of the major excretion products of several species of Thiobacillus and Nitrobacter agilis is pyruvate which has been detected at concentrations up to $10^{-4} \mathrm{M}$. The explanation for the excretion of pyruvate which may reach growth inhibiting levels in these cultures is not known.

It has been pointed out by several authors that the extensive excretion of organic compounds by obligate chemolithotrophs has ecological implications (Pan and Umbreit, 1972b; Kuenen, 1975). Furthermore the excretion of organic compounds also must have physiological implications which might be related to the phenomenon of obligate chemolithotrophy, which is still not very well understood.

In the course of quantitative studies on the physiology of thiosulfate-limited chemostat cultures of Thiobacillus neapolitanus (Kuenen, 1979) in our laboratory it became clear that this organism was excreting high concentrations of organic compounds into the medium.

One of the major excretion products was identified as glycolate. This finding seemed extremely interesting in the light of the well-known excretion of glycolate by both eukaryotic and prokaryotic photoautotrophic organisms (for review see Fogg, 1975; Tolbert and Ryan, 1976).

Therefore it was decided to study the excretion of organic compounds by $T$. neapolitanus in detail. The chemostat was chosen as a tool for investigation in order to be able to grow this organism under well defined and reproducible conditions. The first results of this research already have been reported previously (Cohen and Kuenen, 1976). 


\section{Materials and Methods}

Organisms. Thiobacillus neapolitanus - strain X was used in most experiments. Thiobacillus A2 (Taylor and Hoare, 1969) was obtained from Dr. D. W. Smith. Thiomicrospira pelophila - strain 3 was freshly isolated from marine mud (Kuenen and Veldkamp, 1972). The organisms were maintained as described previously (Kuenen and Veldkamp, 1972, 1973).

Media. The following medium was used for $T$. neapolitanus $(\% \mathrm{w} / \mathrm{v})$ $\mathrm{NH}_{4} \mathrm{Cl}, 0.1 ; \mathrm{MgSO}_{4} \cdot 7 \mathrm{H}_{2} \mathrm{O}, 0.15 ; \mathrm{K}_{2} \mathrm{HPO}_{4}, 0.05 ; \mathrm{KH}_{2} \mathrm{PO}_{4}, 0.05 ;$ $\mathrm{Na}_{2} \mathrm{~S}_{2} \mathrm{O}_{3} \cdot 10 \mathrm{H}_{2} \mathrm{O}, 1.0$ in deionized water. Two milliliter of a trace elements mixture (Vishniac and Santer, 1957) were added per liter of medium. The final $\mathrm{pH}$ was 6.8 . Phosphate and thiosulfate solutions both were autoclaved separately in $10 \%$ of the final volume.

Continuous Culture. The continuous culture equipment used was described by Harder et al. (1974). A detailed description of the routine operation of the continuous culture has been given by Kuenen and Veldkamp (1973). The oxygen concentration was monitored by a galvanic lead-silver oxygen electrode and was controlled automatically using an electronic feedback control between the oxygen electrode and the rate of stirring. Thiosulfate limited cultures of $T$. neapolitanus were maintained at $\mathrm{pH} 6.8$ by automatic titration with $1 \mathrm{M} \mathrm{Na}_{2} \mathrm{CO}_{3}$. Thiobacillus $\mathrm{A} 2$ and Thiomicrospira pelophila were grown in the chemostat as described previously (Kuenen and Veldkamp, 1973; Kuenen, 1979).

All cultures were regularly checked for contamination using the following test medium $(\% \mathrm{w} / \mathrm{v})$ glucose 0.2 ; yeast extract 0.5 ; peptone, 0.3 and $\mathrm{Na}$ acetate, 0.1 or $\mathrm{Na}$ lactate, 0.1 in tap water $\mathrm{pH}$ 7.0 .

Viability. The viability of the chemostat cultures was checked according to the method of Postgate (1969) and was found to be always more than $95 \%$. The culture supernatant had invariably low absorbancy at 260 and $280 \mathrm{~nm}$ indicating a very low number of lysed cells.

${ }^{14} \mathrm{CO}_{2}$ Uptake and Excretion of Organic Compounds. After a steady state in the chemostat had been established (after, at least, five volume changes and a steady density for at least two volume changes) $1 \mathrm{ml}$ of $\mathrm{NaH}^{14} \mathrm{CO}_{3}$ solution containing $100 \mu \mathrm{Ci}$ of a specific activity of $55 \mathrm{mCi} / \mathrm{mmol}$ was added to the growth vessel. Immediately thereafter, $4 \mathrm{ml}$ of $0.1 \mathrm{M} \mathrm{NaHCO}_{3}$ was introduced. Samples of $6-7 \mathrm{ml}$ were taken immediately after addition of the bicarbonate. Additional samples were taken every $15 \mathrm{~min}$. An hour after the addition of bicarbonate the whole culture was harvested.

For the determination of total counts, two $0.5 \mathrm{ml}$ samples were put in $10 \mathrm{ml}$ of scintillation liquid and the samples were counted immediately. The scintillation liquid consisted of a mixture of $2: 1$ toluene and Triton $X$ and $5 \mathrm{~g} / 1$ of PPO. For the determination of the percentage of organic material excreted samples were treated as follows: $1.5 \mathrm{ml}$ samples were filtered through $0.22 \mu$ membrane filters (Sartorius) and the filtrate was collected. The filters were washed with $15 \mathrm{ml} 0.5 \%$ phosphate buffer at $\mathrm{pH} 7.0$. The filters were placed in a scintillation vial after addition of $0.1 \mathrm{ml}$ of $0.1 \mathrm{M} \mathrm{HCl}$ and were left open to dry overnight. The supernatant was treated with $0.05 \mathrm{ml} 1 \mathrm{M}$ $\mathrm{Na}_{2} \mathrm{CO}_{3}$ followed by $0.05 \mathrm{ml} 3 \mathrm{~N} \mathrm{H}_{2} \mathrm{SO}_{4}$ and was aerated for $20 \mathrm{~min}$ in a stream of air in order to chase out any radioactive ${ }^{14} \mathrm{CO}_{2}$

A control experiment with $\mathrm{NaH}^{14} \mathrm{CO}_{3}$ had shown that the radioactivity was completely removed after $10 \mathrm{~min}$. Duplicates of $0.5 \mathrm{ml}$ of the treated samples were counted. Samples of $0.5 \mathrm{ml}$ of nonfiltered cultures were treated as described above for measurement of total fixation of $\mathrm{CO}_{2}$ into organic matter. Cell samples were counted for $10 \mathrm{~min}$ in a liquid scintillation counter Nuclear Chicago model Mark 2. Counts were corrected for quenching. The counts on the filter plus the counts of the supernatant were found to be always $90-$ $105 \%$ of the counts of the non-filtered sample. The ${ }^{14} \mathrm{CO}_{2}$ introduced was rapidly removed from the culture by aeration and was chased by continuous titration with unlabeled sodium carbonate.

A time course experiment showed that in all experiments where $\mathrm{NaH}^{14} \mathrm{CO}_{3}$ was introduced to the cultures, the label incorporated into cell material and in excreted organic matter increased during the first $15 \mathrm{~min}$ after addition of label and then remained constant (corrected for the dilution rate) until harvesting of the culture. In a later stage of the investigations total organic carbon excreted was measured by a total organic carbon analyser (TOC, Beckman, U.S.A.). These analyses confirmed our results obtained with radioactive bicarbonate.

Ether Extraction and Chromatography. The harvested cultures were centrifuged for $20 \mathrm{~min}$ at $12,000 \times \mathrm{g}$ at $4^{\circ} \mathrm{C}$ in a Sorvall $\mathrm{RC} 2 \mathrm{~B}$ centrifuge. The supernatant was filtered through a G5 sintered glass Schott filter apparatus. 1 Liter of the filtrate was concentrated to $40 \mathrm{ml}$ in a vacuum flash evaporator (Büchi, Germany) at $45^{\circ} \mathrm{C}$. The concentrate was acidified with concentrated $\mathrm{H}_{2} \mathrm{SO}_{4}$ to $\mathrm{pH}$ 2.5. The acidified concentrate was placed in a reflux apparatus with $100 \mathrm{ml}$ diethylether and was refluxed for $16 \mathrm{~h}$. The ether was then evaporated with a stream of nitrogen and the dry material was redissolved in $2 \mathrm{ml}$ methanol. Duplicates of $0.5 \mathrm{ml}$ of the water phase and $0.01 \mathrm{ml}$ of the methanol solution were taken for total count measurements. Samples of $0.1 \mathrm{ml}$ were taken for cellulose thin layer chromatography. The following organic acids ( $0.1 \mathrm{mg}$ dissolved in methanol) were used as references: pyruvic acid, hydroxypyruvic acid, succinic acid, glycolic acid, fumaric acid, glyoxylic acid, glyceric acid, malic acid, citric acid, ascorbic acid and serine.

The chromatograms were developed for $4-5 \mathrm{~h}$ at room temperature in a mixture of: ethylacetate: acetic acid: water, $3: 3: 1(\mathrm{v} / \mathrm{v} / \mathrm{v})$. The chromatograms were scanned for radioactive counts on a Packard 3307 chromatogram scanner. After scanning, the chromatogram was sprayed with a $0.01 \%(\mathrm{w} / \mathrm{v})$ acridine orange solution and then with a commercial ninhidrine aerosol (Merck) for visual identification of the spots. $R_{f}$-values of the radioactive scanner were compared to the visual spots.

Chemicals. All chemicals used were of analytical grade (Merck, Fluka and BDH). HPMS (2-pyridylhydroxymethanesulfonate, chemically pure) was obtained from Fluka and Aldrich. The two different brands of HPMS had identical inhibitory effects on cultures of thiobacilli (see Results section).

\section{Results}

Excretion of organic compounds by the autotrophic Thiobacillus neapolitanus was measured in thiosulfatelimited continuous cultures at a fixed dissolved oxygen concentration $\left(\mathrm{pO}_{2}\right)$ of $60 \%$ air saturation. Using pulse labeling of ${ }^{14} \mathrm{CO}_{2}$ as described in the Methods section, we could follow the excretion of organic compounds into the culture medium expressed as a percentage of labeled $\mathrm{CO}_{2}$ fixed into cellular material. Measurements were done at different dilution rates (= growth rates) under steady state conditions and the results are summarized in Fig. 1.

A constant excretion of $8.5 \%$ of total $\mathrm{CO}_{2}$ fixed was observed at the higher dilution rates. Below a dilution rate of $0.2 \mathrm{~h}^{-1}$ the excretion increased with decreasing dilution rate up to $15 \%$ excretion measured at a dilution rate of $0.03 \mathrm{~h}^{-1}$. The excretion at the lower dilution rates cannot be attributed to low viability of the cells as even at the lowest dilution rate the viability was above $95 \%$. 


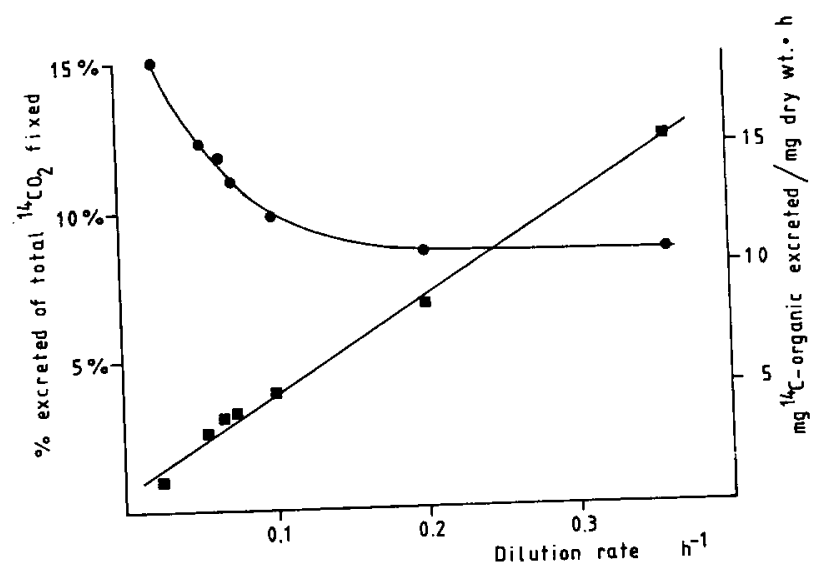

Fig. 1. Excreted ${ }^{14} \mathrm{C}$-organic compounds as the $\%$ of the total ${ }^{14} \mathrm{CO}_{2}$ fixed $(\bullet)$, and the rate of excretion of ${ }^{14} \mathrm{C}$-organic compounds $(\square)$ in thiosulfate-limited chemostat cultures of Thiobacillus neapolitanus as a function of the dilution rate (specific growth rate). Cells were grown

In the same figure the rate of excretion of organic compounds is also indicated showing an increase with increasing growth rate. A maximal rate of excretion of about $15 \mu \mathrm{g}$ organic carbon per mg dry weight per hour $(26 \mu \mathrm{g} \mathrm{C} / \mathrm{mg}$ protein $\cdot h)$ was measured at a growth rate of $0.36 \mathrm{~h}^{-1}$.

In an attempt to identify the excreted organic compounds, the supernatants of the cultures at various dilution rates were collected, acidified to $\mathrm{pH} 2.5$ and extracted with diethylether as described under Methods. The ether-soluble fraction was chromatographed as described under Methods.

The chromatogram of the ether extract showed one major spot at an $R_{f}$-value of 0.69 which fitted with the $R_{f}$-value of glycolic acid and had the same tint when sprayed with acridine and ninhidrine. Table 1 shows the $R_{f}$-values and different colours of the compounds from the ether extract and the reference compounds.

The tentative identification of glycolate later was confirmed by the method of Calkins (Lewis and Weinhouse, 1957) which gave a positive typical blue reaction with the culture supernatant while interfering compounds such as pyruvic acid and glyoxylic acid produced a greyish colour. Later work done in our laboratory has further proved the identity of glycolic acid by using combined gas-liquid chromatography and mass spectroscopy (R. F. Beudeker and J. G. Kuenen, unpublished results).

Glycolate was the major organic compound excreted up to a dilution rate of $0.2 \mathrm{~h}^{-1}$ but not the only one. At a dilution rate of $D=0.07 \mathrm{~h}^{-1}$ about half of the total excretion was found to be ether-extractable material. Of this material about $80 \%$ was found to be
Table 1. $R_{f}$ values and specific colours developed after spraying with acridine orange and ninhidrine solutions of references and excreted organic compounds. Excreted organic compounds were obtained by ether extraction of culture supernatants of chemostat grown cultures of $T$. neapolitanus

\begin{tabular}{|c|c|c|c|}
\hline \multirow[t]{2}{*}{ Compound } & \multirow[t]{2}{*}{$R_{f}$ Value } & \multicolumn{2}{|l|}{ Colour } \\
\hline & & Acridine & Ninhidrine \\
\hline Glycolate & 0.68 & yellow & brown \\
\hline Succinate & 0.82 & yellow & brown \\
\hline Hydroxy- & & & \\
\hline pyruvate & $\begin{array}{l}0.81 \\
0.48\end{array}$ & $\begin{array}{l}\text { yellow } \\
\text { vellow }\end{array}$ & $\begin{array}{l}\text { vlolet } \\
\text { blue-pink }\end{array}$ \\
\hline Pyruvate & $\begin{array}{l}0.48 \\
0.87\end{array}$ & yellow & $\begin{array}{l}\text { blue-pink } \\
\text { yellow }\end{array}$ \\
\hline Fumarate & $\begin{array}{l}0.87 \\
0.72\end{array}$ & yellow & $\begin{array}{l}\text { yellow } \\
\text { yellow }\end{array}$ \\
\hline Glyoxalate & $\begin{array}{l}0.72 \\
0.18\end{array}$ & yellow & $\begin{array}{l}\text { yellow } \\
\text { deep violet }\end{array}$ \\
\hline Serine & $\begin{array}{l}0.18 \\
0.28\end{array}$ & brown & $\begin{array}{l}\text { deep violet } \\
\text { deep violet }\end{array}$ \\
\hline Glycine & 0.28 & brown & deep violet \\
\hline Glyceric acid & 0.51 & brown & brown \\
\hline Ascorbate & 0.41 & brown & brown \\
\hline Malate & 0.56 & yellow & yellow \\
\hline Citrate & 0.45 & yellow & yeliow \\
\hline Excreted & & & \\
\hline glycolate & $0.67-0.69$ & yellow & brown \\
\hline $\begin{array}{l}\text { Unknown } \\
\text { compound }\end{array}$ & $0.79-0.82$ & yellow & brown \\
\hline
\end{tabular}

glycolate. Another distinctive ether soluble compound which was found to account for about $1 \%$ of the total $\mathrm{CO}_{2}$ fixed, has not yet been identified. This compound was found repeatedly on our chromatogram and had a constant $R_{f}$-value of 0.82 and had the same colour reaction as succinate. Gas liquid chromatography showed, however, that the unknown compound was not succinate. Above a dilution rate of $0.3 \mathrm{~h}^{-1}$ more than $90 \%$ of the excreted compounds was not ether soluble and only traces of glycolate could be detected.

The positive identification of glycolate as the major excreted product drew our attention to the excretion of this compound by (cyano)bacteria and algae (Fogg, 1975; Cheng et al., 1972; Codd and Smith, 1974). Excretion of glycolate is commonly attributed to the oxygenase activity of ribulose-1,5-bisphosphate (RUBP)-carboxylase and is believed to be the outcome of a competition of $\mathrm{CO}_{2}$ and $\mathrm{O}_{2}$ for the active site of the enzyme RUBP carboxylase (for review see Chollet, 1977). We have therefore tested the effect of different dissolved $\mathrm{O}_{2}$ concentrations on the amount of organic products excreted by $T$. neapolitanus at a fixed growth rate of $0.07 \mathrm{~h}^{-1}$.

The results are given in Fig. 2. The total excretion of organic compounds was found to drop to $4.9 \%$ at a $\mathrm{pO}_{2}$ of $5 \%$ air saturation as compared to $8.6 \%$ found under 


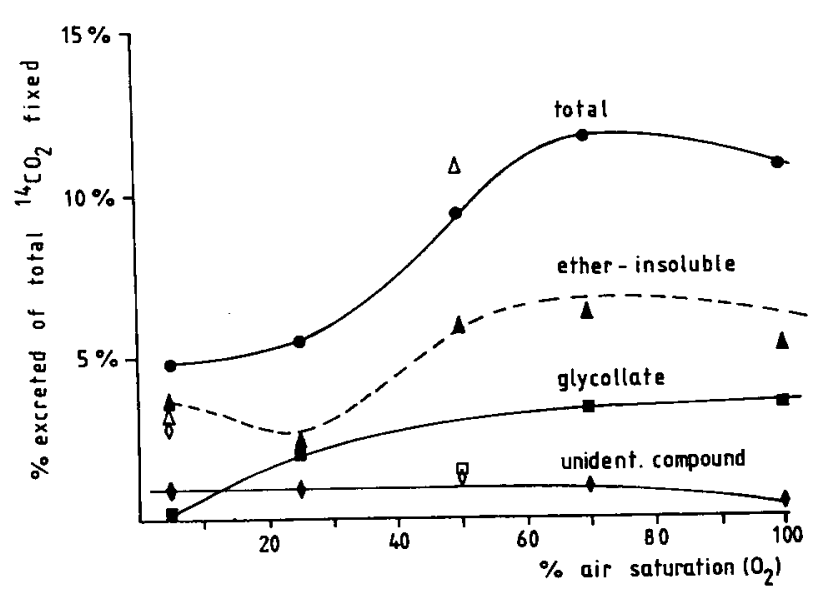

Fig. 2. Excreted ${ }^{14} \mathrm{C}$-organic compounds as the $\%$ of the total ${ }^{14} \mathrm{CO}_{2}$ fixed in thiosulfate-limited chemostat cultures of $T$. neapolitanus as a function of the $\mathrm{pO}_{2}$ expressed as \% air saturation. Cells were grown in thiosulfate minerals medium at $D=0.07 \mathrm{~h}^{-1}$. The cultures were grown at normal $\mathrm{CO}_{2}$ concentrations (closed symbols) and at $5 \%$ (v/v) $\mathrm{CO}_{2}$ in the gas phase (open symbols). total excreted ${ }^{14} \mathrm{C}$ organic compounds; $\Delta$ ether insoluble ${ }^{14} \mathrm{C}$-organic compounds; ${ }^{14} \mathrm{C}$-glycolate; $\bullet$ single, ether soluble, unidentified ${ }^{14} \mathrm{C}$-compound

$50 \%$ air saturation. Glycolate was not detectable at $5 \%$ air saturation. At a $\mathrm{pO}_{2}$ of $70 \%$ air saturation $3.5 \%$ of the total $\mathrm{CO}_{2}$ fixed was excreted as glycolate which makes up to about $50 \%$ of the total organic excretion under these conditions. At $100 \%$ air saturation glycolate contributed to about $60 \%$ of the total excretion. Oxygen was never growth limiting even at a $\mathrm{pO}_{2}$ of $5 \%$ air saturation and the total cell yield under the different oxygen tensions was found to be the same. When $5 \%$ $\mathrm{CO}_{2}$ was included in the air fed to the culture, the total excretion increased both with $\mathrm{pO}_{2}$ of $5 \%$ and $50 \%$ air saturation. Under $50 \%$ air saturation glycolate excretion decreased from the $3.5 \%$ with no addition of $\mathrm{CO}_{2}$ to $1.8 \%$ when $5 \% \mathrm{CO}_{2}$ was added. At $5 \%$ air saturation in the presence of $5 \% \quad \mathrm{CO}_{2}$ again no glycolate was detectable.

The effect of oxygen on the excretion of the other unidentified ether extractable compound, mentioned before, was opposite to the effect on glycolate excretion. The contribution of this compound was $1-$ $1.2 \%$ of the total $\mathrm{CO}_{2}$ fixed at lower $\mathrm{pO}_{2}$ levels and decreased to $0.2 \%$ under $100 \%$ air saturation. The nature of this compound as well as the other non ether extractable compound is presently under investigation in our laboratory.

Effect of HPMS - an Inhibitor of Glycolate Metabolism. The surprisingly high concentration of glycolate in the growth medium of $T$. neapolitanus raised the question whether this organism would have any significant metabolic turnover of glycolate. In this
Table 2. Effect of an inhibitor of glycolate oxidation (2 mM HPMS) on the glycolate excretion of thiosulfate-limited chemostat cultures of $T$. neapolitanus. Cells were grown in thiosulfate minerals medium, at $D=0.07 \mathrm{~h}^{-1}$

\begin{tabular}{ll}
\hline Minutes after addition & $\begin{array}{l}\text { Concentration of glycolate } \\
\mathrm{mg} / \text { liter }\end{array}$ \\
\hline Control & 30 \\
0 & 34 \\
60 & 26 \\
120 & 26 \\
180 & 26 \\
240 & 26 \\
300 & 26 \\
\hline
\end{tabular}

a As measured with the method of Calkins (Lewis and Weinhouse, 1957)

case one would expect a higher excretion in the presence of an inhibitor of glycolate metabolism such as HPMS (Zelitch, 1957; Codd and Smith, 1974). However, when $2 \mathrm{mM}$ HPMS was added to the steady state culture of $T$. neapolitanus grown at $D=0.07 \mathrm{~h}^{-1}$ no such increase was observed (Table 2). Increasing the HPMS concentration to $10 \mathrm{mM}$ led to a complete inhibition of growth and wash out of the culture. In spite of the arrest of growth complete oxidation of thiosulfate to sulfate continued for several hours. The glycolate present in the medium did not increase and was washed out at the rate of the dilution of the culture.

Glycolate Excretion by Other Chemolithotrophic Sulfur Bacteria. Thiomicrospira pelophila, another obligate chemolithotrophic sulfur bacterium did not excrete significant amounts of glycolate into its growth medium when grown at $\mathrm{pO}_{2}$ of $50 \%$ air saturation at a dilution rate of $0.05 \mathrm{~h}^{-1}$ under thiosulfate limitation. Total carbon excretion was less than $2 \mathrm{mg} / \mathrm{l}$ and the Calkins assay showed a concentration of glycolate just at the detection level $(0.5 \mathrm{mg}$ glycolate/1). Cultivation of $T$. pelophila under $\mathrm{CO}_{2}$ limitation or $\mathrm{NH}_{4}^{+}$limitation was equally ineffective in increasing glycolate excretion.

Thiobacillus A2, a facultative chemolithotroph, did not excrete detectable amounts of glycolate when grown under autotrophic conditions at $50 \%$ air saturation under thiosulfate limitation. This is not surprising since $T$. A 2 has the potential to growth on glycolate as the only carbon and energy source (J. C. Gottschal and J. G. Kuenen, unpublished results). HPMS (5$10 \mathrm{mM}$ ) had a growth inhibitory effect on thiosulfate limited cultures of Thiobacillus A2 very similar to that observed with cultures of $T$. neapolitanus. Again no detectable quantities of glycolate were excreted under these conditions. 
Y. Cohen et al.: Excretion of Glycolate by Thiobacillus neapolitanus

\section{Discussion}

We have studied the excretion of organic compounds by the obligately chemolithotrophic Thiobacillus neapolitanus in continuous culture. The chemostat turned out to be an extremely useful tool to study excretion processes at different growth rates under well defined environmental conditions such as constant $\mathrm{pH}$ and $\mathrm{pO}_{2}$.

In contrast to previous work with batch cultures of obligate chemolithotrophs (Borichewski, 1967; Pan and Umbreit, 1972a; Schnaitman and Lundgren, 1965) glycolate was found to be the major excretion product in chemostat cultures of $T$. neapolitanus grown at a large range of different dilution rates (specific growth rates). Pyruvate could not be detected, though it could easily be found in our assay system when pyruvate was added to the culture supernatant (unpublished results).

$T$. neapolitanus cultures grown at high dilution rates $\left(>0.3 \mathrm{~h}^{-1}\right)$ still did excrete substantial amounts of organic carbon but the contribution of glycolate was negligible. This may explain why glycolate has never been found before in batch cultures which, at least in theory, grow at maximum growth rates.

The total excretion of organic compounds by $T$. neapolitanus was found to vary from $15 \%$ of the total $\mathrm{CO}_{2}$ fixed at a dilution rate of $0.03 \mathrm{~h}^{-1}$ to $8.5 \%$ at a dilution rate of $0.36 \mathrm{~h}^{-1}$. At a dilution rate of $0.07 \mathrm{~h}^{-1}$ the rate of glycolate excretion was $4-5 \mu \mathrm{g} / \mathrm{h} \cdot \mathrm{mg}$ dry weight. This rate of excretion is lower than that found in various eukaryotic and prokaryotic photosynthetic organisms which may show 5-10 fold higher rates (Hess et al., 1967; Codd and Smith, 1974; Döhler and Braun, 1971; Oliver and Zelitch, 1977), but higher than found in the autotrophically grown hydrogen bacterium Alcaligenes eutrophus, which excreted 0.5$1 \mu \mathrm{g} / \mathrm{h} \cdot \mathrm{dry}$ weight when suspended in buffer (Codd et al., 1977). T. neapolitanus is thus the first nonphotosynthetic organism shown to excrete substantial amounts of glycolate under normal growth conditions.

The effect of varying oxygen concentrations on the excretion of glycolate strongly indicates that this excretion is a result of the oxygenase activity of ribulose bisphosphate carboxylase (for reviews see Chollet, 1977; Jensen and Bahr, 1977). This explanation is further supported by the effect of higher $\mathrm{CO}_{2}$ concentrations $(5 \% \mathrm{v} / \mathrm{v})$ in the gas phase which reduced the excretion of glycolate at $50 \%$ air saturation to about half of that found at normal $\mathrm{CO}_{2}$ concentration (Fig. 2). Later work has shown that the glycolate excretion was drastically increased when $T$. neapolitanus was grown at a dilution rate of $0.07 \mathrm{~h}^{-1}$ under $\mathrm{CO}_{2}$ limitation.
In autotrophically grown Alcaligenes eutrophus which excretes only low quantities of glycolate (when suspended in buffer), significant activities of both glycolate phosphate phosphates and glycolate dehydrogenase have been demonstrated (Codd et al., 1977). In this organism the inhibitor of glycolate dehydrogenase, HPMS, caused a largely enhanced excretion of glycolate. The lack of any effect of $2 \mathrm{mM}$ HPMS on glycolate excretion in cultures of $T$. neapolitanus seems to indicate that this enzyme is either insensitive to HPMS or is quantitatively unimportant for the metabolism of glycolate. Work is in progress to investigate whether the absence or low activities of this enzyme and the lack of an alternative metabolic pathway for glycolate metabolism could explain the excretion of glycolate by this organism.

In general, the substantial excretion of organic compounds under condition of energy limitation by the obligately chemolithotrophs, who depend on carbon dioxide as their major carbon source, seems to be a waste of energy. Although the excretion of organic compounds may be caused by imbalanced growth or stress conditions in many bacteria (see Tempest and Neyssel, 1978) this does not seem to be the case in cultures of various thiobacilli and other obligate chemolithotrophs as these cultures, grown under a variety of conditions, invariably contain substantial quantities of extracellular organic compounds. It is conceivable that in the obligately chemolithotrophic organism, which are specialized to autotrophic growth the maintenance of an elaborate fine control system on the regulation of the synthesis of metabolites would be more energy consuming than some overproduction and subsequent loss of a certain quantity of organic compounds.

Since long it has been known that not only chemolithotrophs but also other autotrophic organisms like the cyanobacteria and the green algae excrete appreciable amounts of organic compounds into their environment (Belly et al., 1973; Fogg, 1975). Apart from considerations concerning a possible waste of energy by excretion of certain metabolic products it should be realized that the production of organic compounds may be ecologically advantageous to the organisms. The excreted organic molecules will serve as substrates for heterotrophic bacteria, and thus one must assume that populations of photo- and chemolithotrophs will always be accompanied by satelite populations of heterotrophic bacteria, which may establish mutualistic relationship with the autotrophs. Several cases have been reported which show stimulation of the growth of the chemo- or photolithotrophs in the presence of heterotrophic bacteria (Lang, 1971; Pan and Umbreit, 1972 b; Kuenen, 1975; Kuenen et al., 1977). 
It has clearly been shown that glycolate excretion by photosynthetic organisms in the natural environment is quantitatively important (Fogg, 1975). Most natural waters have been shown to contain measurable quantities of glycolate (Shah and Wright, 1974; Fogg et al., 1975). It remains to be investigated whether thiobacilli and related organisms will excrete significant amounts of glycolate under natural growth conditions. Thiobacilli are dependent for their growth on the simultaneous presence of both oxygen and a reduced sulfur compound such as sulfide. This implies that these organisms are often restricted to growth at low oxygen concentrations. Under such conditions the potential oxygenase activity may not be expressed. But since these organisms live in gradients which shift with the natural cycles such as the diurnal and tidal cycles, these organisms may be exposed temporarily to high concentrations of both oxygen and the energy substrate. Under these conditions glycolate excretion very well may have an ecological significance.

\section{References}

Belly, R. T., Tansey, M. R., Brock, T. D.: Algal excretion of ${ }^{14} \mathrm{C}$ labeled compounds and microbial interactions in Cyanidium caldarium mats. J. Phycology 9, 123-127 (1973)

Borichewski, R. M.: Keto acids as growth-limiting factors in autotrophic growth of Thiobacillus thiooxidans. J. Bacteriol. 93, 597-599 (1967)

Borichewski, R. M., Umbreit, W. W.: Growth of Thiobacillus thiooxidans on glucose. Arch. Biochem. Biophys. 116, 97-102 (1966)

Cheng, K. H., Miller, A. G., Colman, B.: An investigation of glycolate excretion in two species of blue-green algae. Planta (Berl.) 103, 110-116 (1972)

Chollet, R.: The biochemistry of photorespiration. Trends Bioch. Sci. 2, 155-159 (1977)

Codd, G. A., Smith, B. M. : Glycollate formation and excretion by the purple photosynthetic bacterium Rhodospirillum rubrum. FEBS Letters 48, 105-108 (1974)

Codd, G. A., Bowien, B., Schlegel, H. G.: Glycollate production and excretion by Alcaligenes eutrophus. Arch. Microbiol. 110, 167171 (1977)

Cohen, Y., Kuenen, J. G.: Growth yields and excretion products of Thiobacillus neapolitanus. Abstr. Ann. Meeting Am. Soc. Microbiol. p. 120 (1976)

Döhler, G., Braun, F.: Untersuchung der Beziehung zwischen extracellulärer Glycolsäure-Ausscheidung und der photosynthetischen $\mathrm{CO}_{2}$-Aufnahme bei der Blaualge Anacystis nidulans. Planta (Berl.) 98, 357-361 (1971)

Fogg, G. E.: Biochemical pathways in unicellular plants. In: Photosynthesis and productivity in different environments, pp. 437-457, Int. Biol. Programme, vol. 3, London-New York: Cambridge University Press 1975

Fogg G. E., Burton, N. F., Coughlan, S. J.: The occurrence of glycollic acid in antarctic waters. Br. Antarct. Surv. Bull, 41 \& 42, 193-197 (1975)

Harder, W., Visser, K., Kuenen, J. G.: Laboratory fermenter with an improved magnetic drive. Lab. Pract. 23, 644-645 (1974)
Hess, J. L., Tolbert, N. E., Pike, L. M.: Glycolate biosynthesis by Scenedesmus and Chlorella in the presence or absence of $\mathrm{NaHCO}_{3}$. Planta (Berl.) 74, 278-285 (1967)

Jensen, R. G., Bahr, J. T.: Ribulose-1,5-bisphosphate carboxylaseoxygenase. Ann. Rev. Plant Physiol. 28, 379-400 (1977)

Kuenen, J. G.: Colourless sulfur bacteria and their role in the sulfur cycle. Plant Soil 43, 49-76 (1975)

Kuenem J. G., Cohen, Y., Gottschal, J. C.: Organic excretion products of Thiobacilli in pure and mixed culture. Abstr. 3rd Int. Symp. Environm. Biogeochem., pp. 77-78, Publ. Univ. Oldenburg (1977)

Kuenen, J. G.: Growth yields and "maintenance energy requirement" in Thiobacillus species under energy limitation. Arch. Microbiol. 122, 183-188 (1979)

Kuenen, J. G., Veldkamp, H.: Thiomicrospira pelophila, nov. gen., nov. sp., a new obligately chemolithotrophic colourless sulfur bacterium. Antonie van Leeuwenhoek J. Microbiol. Serol. 38, $241-256$ (1972)

Kuenen, J. G., Veldkamp, H.: Effects of organic compounds on growth of chemostat cultures of Thiomicrospira pelophila, Thiobacillus thioparus and Thiobacillus neapolitanus. Arch. Mikrobiol. 94, 173-190 (1973)

Lang, W.: Enhancement of algal growth in Cyanophyta-bacteria systems by carbonaceous compounds. Can. J. Microbiol. 17, 303-314 (1971)

Lewis, K. F., Weinhouse, S. : Determination of glycolic, glyoxylic and oxalic acids. In: Methods in Enzymology, Vol. 3 (S. P. Colowick, N. O. Kaplan, Eds.), pp. 272-273, New York: Academic Press 1957

Oliver, D. J., Zelitch, I.: Metabolic regulation of glycolate synthesis, photorespiration and net photosynthesis in Tobacco by $\mathrm{L}$ glutamate. Plant Physiol. 59, 688-694 (1977)

Pan, P. C., Umbreit, W. W.: Growth of obligate autotrophic bacteria on glucose in a continuous flow-through apparatus. J. Bacteriol. 109, 1149-1155 (1972a)

Pan, P. C., Umbreit, W. W. Growth of mixed cultures of autotrophic and heterotrophic organisms. Can. J. Microbiol. 18, 153-156 (1972b)

Postgate, J. R.: Viable counts and viability. In: Methods in Microbiology, Vol. 1, (J. R. Norris, D. W. Ribbons, Eds.), pp. 611-628, Academic Press, London and New York 1969

Schnaitman, C., Lundgren, D. G.: Organic compounds in the spent medium of Ferrobacillus ferrooxidans. Can. J. Microbiol. 11, 23-27 (1965)

Shah, N. M., Wright, R. T.: The occurrence of glycolic acid in coastal sea water. Marine Biology, 24, 121-124 (1974)

Taylor, B. F., Hoare, D. S.: New facultative Thiobacillus and a reevaluation of the heterotrophic potential of Thiobacillus novellus. J. Bacteriol. 100, $487-497$ (1969)

Tempest, D. W., Neijssel, O. M.: Eco-physiological aspects of microbial growth in aerobic nutrient-limited environments. Adv. Microb. Ecol. 2, 105 - 153 (1978)

Tolbert, N. E., Ryan, F. J.: Glycolate biosynthesis and metabolism during photorespiration. In: $\mathrm{CO}_{2}$-metabolism and Plant Productivity (R. H. Burris, C. C. Black, Eds.) pp. 141-159, Baltimore, Md.: University Press 1976

Vishniac, W., Santer, M.: The thiobacilli. Bacteriol. Rev. 21, 195213 (1957)

Zelitch, I.: $\alpha$-Hydroxysulfonates as inhibitors of the enzymatic oxidation of glycolic and lactic acids. J. Biol. Chem. 224, 251 260 (1957)

Received March 12, 1979 